\title{
20 The effect of fragmentation on spider richness (Arachnida: Araneae) in montane semideciduous seasonal forest
}

Flávio Eduardo Vilas Boas Junior ${ }^{1}$

Amanda da Silva Ferreira ${ }^{2}$

Marcos Magalhães de Souza ${ }^{3}$

\begin{abstract}
The fragmentation process that has altered natural environments has been widely discussed, as it causes changes in communities and compromises different environmental functions. In this sense, this study was based on the evaluation of fragmentation on araneofauna of semideciduous seasonal forest fragments, phytophysiognomy belonging to the Atlantic Forest. The study was conducted in three fragments in the municipality of Inconfidentes, southern Minas Gerais, from April 2014 to March 2015. The results showed that there is a similarity in the composition of spider species among the sampled fragments and that the size of the fragment is positively correlated with species richness. Our data show that smaller fragments must be preserved and that agricultural areas maintain the integrity of adjacent forest areas to benefit from the predation dynamics that spiders exert on pests that affect plantations.
\end{abstract}

Keywords: Araneofauna. Atlantic Forest. Fragment size.

\section{Introduction}

The Atlantic Forest has suffered severely from the fragmentation process due to anthropogenic activities, such as the conversion of land use to livestock and agriculture, as well as wood extraction and human occupation, which alters the dynamics of biological communities, and it is not foreseen in continuous natural systems (MYERS, 1980; NOSS; CSUTI, 1994; DEAN, 1996; LAURANCE; BIERREGAARD, 1997).

This process affects ecosystems negatively (LAURANCE, VASCONCELOS, 2009), causing the extinction of species and compromising different environmental services, such as pollination, seed dispersion, biological control, and nutrient recycling (RUSCHEINSKY, 2004; HANSKI et al., 2013).

To evaluate the impacts of forest fragmentation, Uetz (1976) suggests the use of arthropods because they are easy to sample, small (easy to transport and store), abundant and diverse, and are quite important in the cycle of nutrients and energy flow in ecosystems, especially the spiders.

The order Araneae represents, in the numberof species, the second largest order of arachnids and the seventh of the Reino Animalia, with 48,385 species and 4,165 genera distributed in 120 families (PLATNICK, 2020). They are of great ecological importance because they are generalist and abundant predators in different terrestrial ecosystems (SANDIDGE, 2004; VITT; CALDWELL, 2013),

1 Universidade Federal de Lavras (UFLA). Mestre em Ecologia Aplicada.juniorfevb@gmail.com.

2 Instituto Federal de Educação, Ciência e Tecnologia do Sul de Minas (IFSULDEMINAS) - Campus Inconfidentes. Graduanda em Licenciatura em Ciências Biológicas.amanda1.ferreira@alunos.ifsuldeminas.edu.br

3 IFSULDEMINAS - Campus Inconfidentes. Professor efetivo. Inconfidentes/MG. marcos.souza@ifsuldeminas.edu.br 
and they can be used in biological control programs of agricultural pests (SUNDERLAND; SAMU,2000; HANNA; ZALOM; ROLTSCH, 2003), including in Brazil (RINALDI; MENDES; CADY, 2002; OTT; OTT; WOLFF, 2007; RODRIGUES; MENDONCA; OTT, 2008).

Brazil has the highest spider biodiversity in the neotropical region, with approximately 3,203 species distributed in 659 genera belonging to 72 families (BRESCOVIT; OLIVEIRA; SANTOS, 2011). The state of Minas Gerais has about 500 species and ranks sixth among the Brazilian states in araneofauna (BRESCOVIT; OLIVEIRA; SANTOS, 2011). However, the number should be higher, considering the geographical area, the diversity of ecosystems, and the scarcity of studies (BRESCOVIT, 1999), even though inventory work has increased in recent decades (OLIVEIRA, 2011).

The state of Minas Gerais is composed of different biomes, and in the southern region of the state, the predominant phytophysiognomy is the semideciduous seasonal forest dominated by the Atlantic Forest (OLIVEIRA-FILHO, 2006). This phytophysiognomy is characterized by the deciduousness of about $50 \%$ of tree species in winter.

We know that spiders suffer a reduction in their populations due to forest fragmentation (BOLGER et al., 2000; GIBB; HOCHULI, 2002), however, there is little information in semideciduous seasonal forest areas. Therefore, we need studies on the effect of fragmentation on the araneofauna of this phytophysiognomy to understand the conservation status of this taxon.

Based on the considerations above, this study aims to evaluate the effect of forest fragmentation on araneofauna in a semideciduous forest in the state of Minas Gerais, and to extend the knowledge about the taxon in the state.

\section{Material and methods}

The study was conducted in three forest fragments $1 \mathrm{~km}$ apart from each other, named $\mathrm{C}$

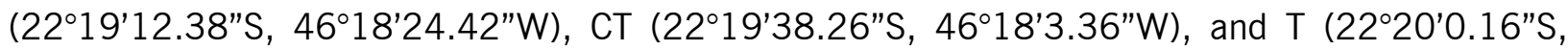
$46^{\circ} 17^{\prime} 50.96^{\prime \prime} \mathrm{W}$ ) in the municipality of Inconfidentes, southern Minas Gerais (FIGURE 1). The municipality is in the Atlantic Forest biome, and the predominant phytophysiognomy is Montana Semidecidual Seasonal Forest (IBGE, 2012). The climate here is classified as CWB (Köppen), with an average temperature of $19.3^{\circ} \mathrm{C}$ and an average annual rainfall of $1,500 \mathrm{~mm}$.

Fragment $\mathrm{C}$ has a total area of 4.9 hectares and its matrix is composed of pasture, while fragments CT (2.6 ha) and T (10.4 ha) have an environment matrix mostly composed of coffee. All are formed by secondary forest at some level of regeneration. In each of the fragments, we made two transects of 50 meters in length each, parallel and $100 \mathrm{~m}$ apart from each other (APPENDIX 1).

For data collection, we chose three methodologies: pitfall traps, entomological umbrella, and night manual collection in transects (OTT; OTT; WOLFF, 2007; PODGAISKI et al., 2007). The sampling was carried out from April 2014 to April 2015, divided into four campaigns, one per season. 
Figure 1 - Site of forest fragments where the spiders were collected in the municipality of Inconfidentes, southern Minas Gerais.
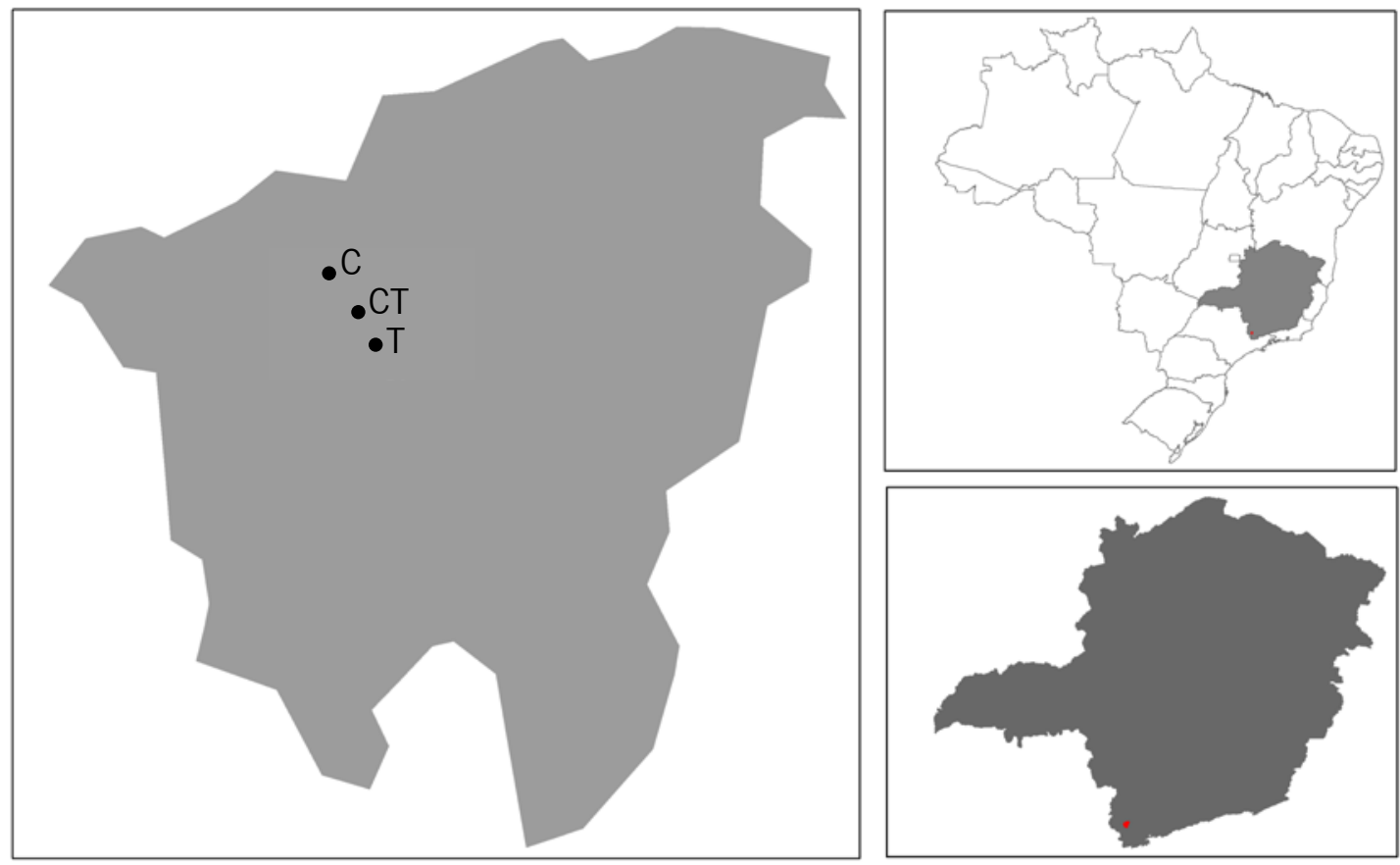

\section{Subtitle}

- Sampling points
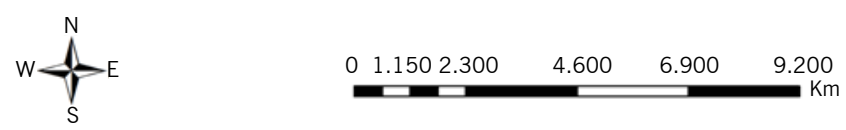

Source: Elaborated by the authors (2020).

Plastic cups $8.5 \mathrm{~cm}$ in diameter and $12.5 \mathrm{~cm}$ in height were used for pitfall traps, with a $70 \%$ ethyl alcohol solution as a preservative liquid. Two wooden rods with a plate (about five centimeters from the ground) were also placed on top of each pitfall to prevent the entry of rainwater and obstruction of traps by dry leaves. The traps were installed in each of the fragments, following the transects. In each transect, 10 traps (five meters equidistant) were installed, in a total of 20 traps. A week after installing them, we returned to the field to collect the material from the traps.

To sample the arboreal araneofauna, we used the entomological umbrella methodology, which consists of a cloth ( $1 \mathrm{~m} \times 1 \mathrm{~m}$ ) arranged on two wooden rods. The researcher stands under a bush or tree, extends the cloth, while another researcher hits the vegetation toward the first, so that spiders fall on the cloth and are then collected with the aid of an entomological forceps. For the collection, the researchers followed the transects in a period of 1 hour each, totaling 6 hours per campaign (24 hours in total).

Manual night-time collection was a complementary method, which consisted of capturing the animals manually with the aid of a headlight and tweezers, while the researcher walked slowly through the transects, looking for structures in the soil and vegetation that could contain spiders. The researchers spent 1 hour per transect, totaling 6 hours per campaign (24 hours in total).

All material collected was stored in a humid medium (70\% alcohol) and deposited in the zoology laboratory of the Federal Institute of Southern Minas Gerais, Inconfidentes Campus, where the partial screening of morphospecies was carried out. Subsequently, the biological material was 
sent to the arachnology laboratory of the Federal University of Minas Gerais (UFMG), where it was identified at the species level.

For statistical analyses, only adults from whom it was possible to reach at least species level were used. First, rarefaction curves were made for each sampling point, using the first-order Jackknife richness estimator with $95 \%$ reliability (EFRON; STEIN, 1981). To test the similarity of the fragments, we made comparisons by the Sorensen index (1948) based on the presence and absence of the species at each of the points, and a cluster grouping generated from this index.

To test the effect of fragmentation on the araneofauna of the fragments, a linear regression was made, correlating richness with the size of the fragment (variable obtained by Google Earth Pro). All tests were done through the R-Studio program (2020).

\section{Results and discussion}

We collected 902 individuals (belonging to 30 families), of which 566 were adults, distributed in 24 families and 107 species, with Theridiidae (23 species), Araneidae (22 species), and Salticidae (12 species) being the ones with the highest richness. The most abundant species was Thwaitesia affinis 0 . Pickard-Cambridge, 1882, with 44 individuals collected (APPENDIX 2), which has already been reported in other studies carried out in distinct phytophysiognomies, behaving as one of the most common ones (HÖFER; BRESCOVIT, 1994; PODGAISKI et al., 2007).

The families with the highest richness in this study are among the richest in the world in the number of species (PLATNICK, 2020), which explains the data obtained in this study. These families were also the most representative in the studies by Ott, Ott, Wolff (2007) and Podgaiski et al. (2007), who used methodologies similar to this study's (entomological umbrella and night-time collection), a factor that may have contributed to this result.

In general, the rarefaction curves per fragment did not reach the asymptote, i.e., there are still more species to be sampled in the areas, as indicated by Jackknife 1 (TABLE 1). From the estimated richness data, we can infer that the insufficient sampling may have happened by the size of the sampled fragments, since in larger fragments a greater richness of species is expected. In this condition, new collections in the study areas are justified, as we know that the increased collection effort generates more reliable data and does not underestimate species richness (OLIVEIRA, 2011).

Table 1 - Sample sufficiency data of the sampling performed at work. Area: name of the fragments selected. Number registered: richness observed in the fragment. Number expected: value pointed out by the first-order jackknife.

\begin{tabular}{ccc}
\hline Fragment analyzed & Richness sampled & Richness estimated \\
\hline C & 70 & 96 \\
CT & 38 & 49 \\
T & 63 & 81 \\
\hline
\end{tabular}

Source: Elaborated by the authors (2020).

The cluster graph generated by the Sorensen index (FIGURE 2) shows that the composition of the araneofauna of areas $C$ and $T$ are more similar to each other (49.6\%), however, the similarities of area C and CT (46.2\%), and CT and T (47.5\%) were also expressive, suggesting that there is a possible dispersion and colonization of spiders among the sampled areas. 
Figure 2 - Cluster graph generated from Sorensen similarity of the sampled areas.

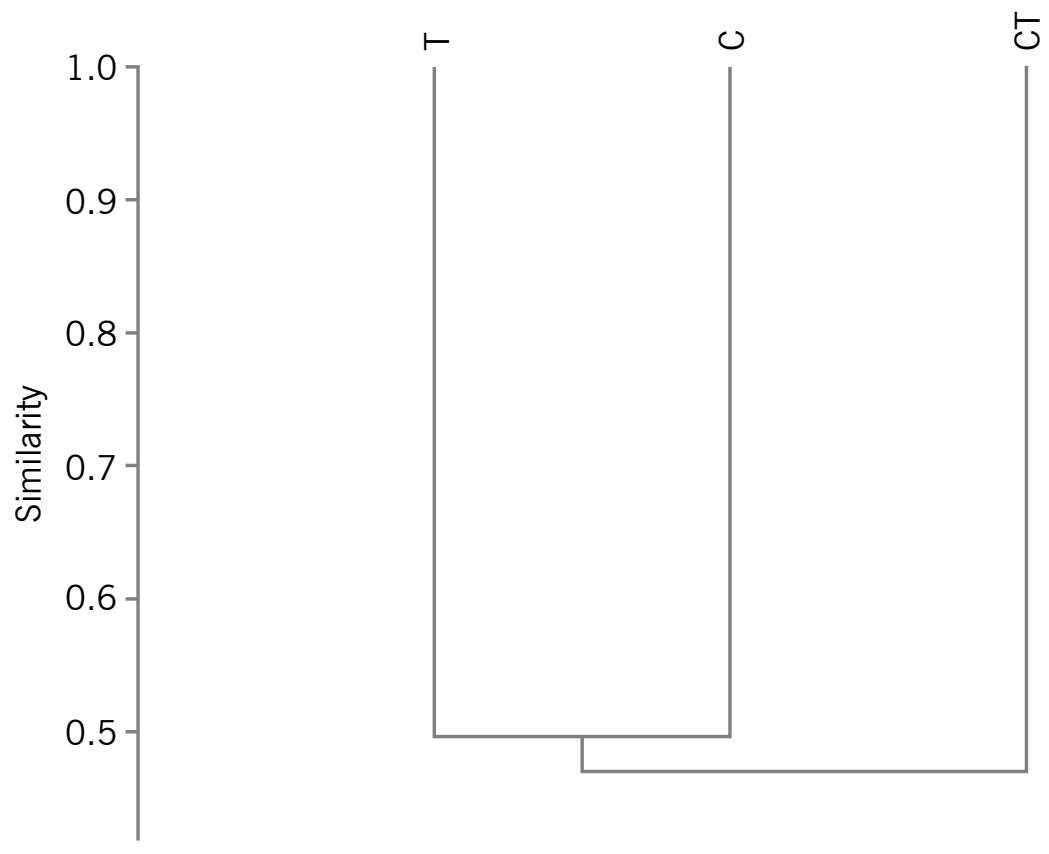

Source: Elaborated by the authors (2020).

Linear regression correlating the total area of the fragment with species richness showed that there is a positive trend explaining $32.4 \%$ of the variation, at which the larger the fragment, the greater the number of species present (FIGURE 3).

Figure 3 - Graph of the linear regression obtained by correlating species richness and fragment size.

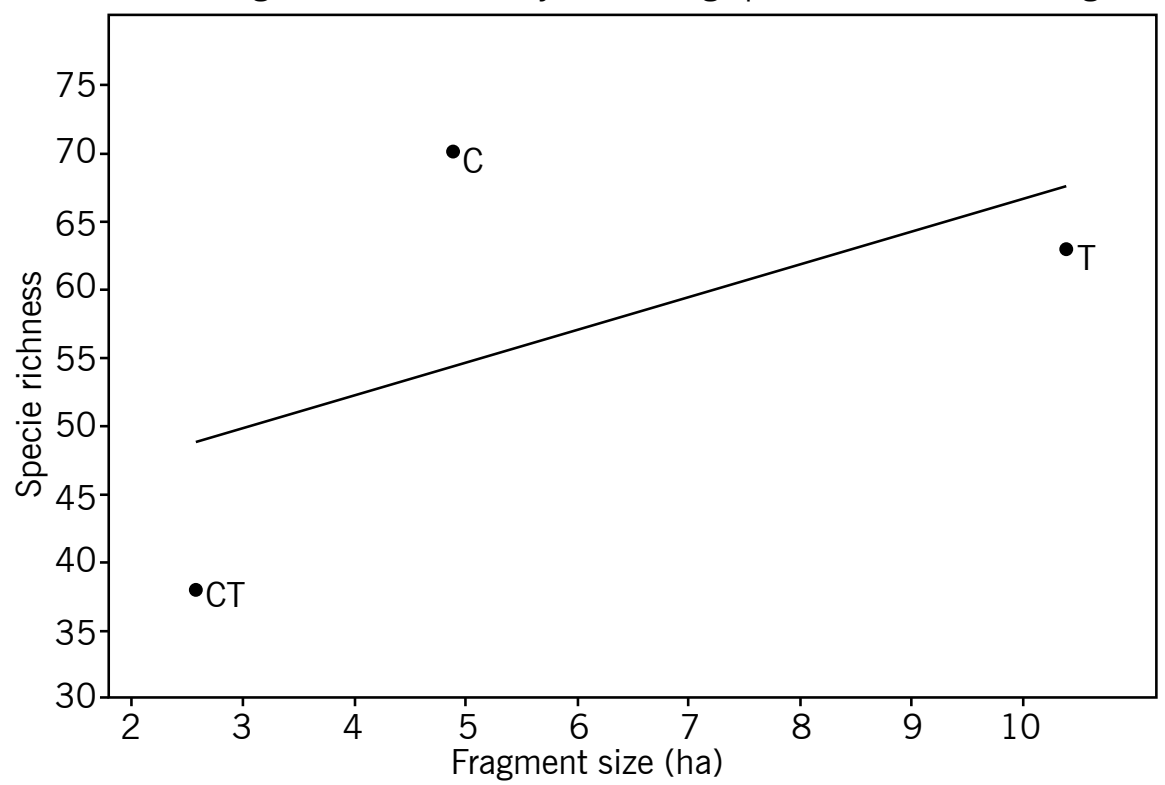

Source: Elaborated by the authors (2020).

From the regression, we observed that the size of the fragment is an important variable for the conservation of araneofauna biodiversity, since larger fragments have a greater richness of species, 
which is corroborated by other studies that show that those animals have their populations reduced due to the fragmentation process (BOLGER et al. 2000; GIBB; HOCHULI, 2002).

Another relevant factor was the presence, in greater richness and abundance, of important families such as Ctenidae and Sparassidae in the larger fragments. Spiders of these families, in general, have wandering habits (nomads), and it is known that these families' species are reduced in fragmented environments (REGO; VENTICINQUE; BRESCOVIT, 2005; REGO; VENTICINQUE; BRESCOVIT, 2007).

The similarity between the fragments sampled should also be considered, especially between fragments $C$ and $T$, which showed the greatest similarity between the fragments (49.6\%), even though fragment $\mathrm{C}$ was isolated by a pasture matrix. The compositional data show that different matrices (coffee and pasture) are not barriers to the dispersion and colonization of spiders, as they can cross large areas (BELL et al., 2005) using the ballooning tactic.

Although the present study evaluated only small fragments (the largest with just over $10 \mathrm{ha}$ ), one should consider their importance in the conservation of spider species, as evidenced by Benati et al. (2010), since these small fragments still show heterogeneity of habitats, which allows the colonization and permanence of spider species.

Aiming at maintaining and ensuring the richness of araneofauna, in addition to its important ecosystem services provided, our data show that smaller fragments must be conserved. We also suggest that agricultural areas maintain the integrity of adjacent forest areas to benefit from the predation dynamics that spiders exert on pests that affect plantations, being a natural and cheaper way to reduce possible damage caused to crops.

\section{Conclusions}

The similarity of the areas was expressive, since the proximity of the areas may have been a factor that helped the dispersion of spiders among the fragments. There is a tendency that the larger the fragment, the greater the richness of spider species.

\section{Acknowledgments}

To Professor Dr. Adalberto J. dos Santos, arachnology laboratory, Federal University of Minas Gerais, for the identification of spider species, and the trainees of the zoology laboratory of IFSULDEMINAS, Inconfidentes Campus, for the assistance in collections.

\section{Efeito da fragmentação sobre a riqueza de aranhas (Arachnida: Araneae) em floresta estacional semidecidual montana}

\section{Resumo}

O processo de fragmentação que tem alterado os ambientes naturais tem sido amplamente discutido, pois provoca alterações nas comunidades e compromete diferentes funções ambientais. Neste sentido, o presente trabalho fundamentou-se na avaliação da fragmentação sobre a araneofauna de fragmentos de floresta estacional semidecidual, fitofisionomia pertencente à Mata Atlântica. 0 estudo foi conduzido em três fragmentos no município de Inconfidentes, sul do estado de Minas Gerais no período de abril de 2014 a março de 2015. Os resultados mostraram que há uma similaridade na 
composição das espécies de aranhas entre os fragmentos amostrados, e que o tamanho do fragmento é correlacionado positivamente com a riqueza de espécies. Nossos dados mostram que fragmentos menores devem ser preservados e que as áreas agrícolas devem manter a integridade das áreas florestais adjacentes, a fim de se beneficiarem da dinâmica de predação que as aranhas exercem sobre as pragas que acometem as plantações.

Palavras-chave: Araneofauna. Mata Atlântica. Tamanho do fragmento.

\section{References}

BELL, J. R.; BOHAN, D. A.; SHAW, E. M.; WEYMAN, G. S. Ballooning dispersal using silk: world fauna, phylogenies, genetics and models. Bulletin of Entomological Research. v. 95, p. 69-114, abr. 2005. Available at: https://doi.org/10.1079/ber2004350. Access on: 24 jun. 2020.

BENATI, K. R.; PERES, M. C. L.; TINOCO, M. S.; BRESCOVIT, A. D. Influência da estrutura de hábitat sobre aranhas (Araneae) de serrapilheira em dois pequenos fragmentos de mata atlântica. Neotropical Biology \& Conservation, v. 5, n. 1, p. 39-46, jan./abr. 2010. Available at: http://dx.doi.org/10.4013/ nbc.2010.51.06. Access on: 24 jun. 2020.

BOLGER, D. T.; SUAREZ, A. V.; CROOKS, K. R.; MORRISON, A. S.; CASE, T. J. Artrópodes em fragmentos de habitat urbano no sul da Califórnia: área, idade e efeitos de borda. Aplicações ecológicas, v. 10, n. 4, p. 1230-1248, ago. 2000.

BRESCOVIT, A. D. Araneae. In: BRANDÃO, C. R. F.; VASCONCELOS, E. M. (Org.). Biodiversidade do Estado de São Paulo, Brasil: Síntese do conhecimento ao final do século XX. Fapesp, São Paulo, p. 45-60, 1999.

BRESCOVIT, A. D.; DE OLIVEIRA, U.; DOS SANTOS, A. J. Aranhas (Araneae, Arachnida) do Estado de São Paulo, Brasil: diversidade, esforço amostral e estado do conhecimento. Biota Neotropica, Campinas, v. 11 n. 1, p. 1-31, dez. 2011. Available at: http://dx.doi.org/10.1590/S1676-06032011000500035. Access on: 24 jun. 2020.

DEAN, W. A Ferro e Fogo: a história e a devastação da Mata Atlântica. São Paulo: Companhia das Letras, 1996. p. 23.

EFRON, B.; STEIN, C. The Jackknife estimate of variance. The Annals os Statistics. v. 9, n. 3, p. 586-596. 1981.

GIBB, H.; HOCHULI, D. F. Fragmentação de habitats em ambiente urbano: fragmentos grandes e pequenos suportam diferentes conjuntos de artrópodes. Conservação biológica, v. 106, n. 1 , p. 91-100, jul. 2002.

HANNA, R.; ZALOM, F. G.; ROLTSCH, W. J. Relative impact of spiders predation and cover crop on population dynamics of Erythroneuravariabilis in a raisin grape vineyard. Entomologia Experimentalis et Applicata, v. 107, p. 177-191, maio 2003. Available at: https://doi.org/10.1046/j.1570-7458.2003.00051.x. Access on: 24 jun. 2020. 
HANSKI, I.; ZURITA, G. A.; BELLOCQ, M. I.; RYBICKI, J. Species-fragmented area relationship. Proceedings of the National Academy of Sciences, PNAS. v. 110, n. 31, p. 12715-12720. Jul., 2013. Available at: https://doi.org/10.1073/pnas.1311491110. Access on: 24 jun. 2020.

HÖFER, H.; BRESCOVIT, A. D.; ADIS, J.; PAARMANN, W. The spider fauna of neotropical tree canopies in Central Amazonia: first results. Studies on Neotropical Fauna and Environment. v. 29, n. 1, p. 23-32, mar. 1994. Available at: https://doi.org/10.1080/01650529409360913. Access on: 24 jun. 2020.

IBGE. Instituto Brasileiro de Geografia e Estatística. Manual técnico da vegetação brasileira. Série manuais técnicos em Geociências. 2. ed. Instituto Brasileiro de Geografia e Estatística, Rio de Janeiro. 275 p. 2012.

LAURANCE, W. F.; BIERREGAARD, R. O. (Eds.). Remanescentes de florestas tropicais: ecologia, manejo e conservação de comunidades fragmentadas. University of Chicago Press. Chicago, 1997.

LAURANCE, W. F.; VASCONCELOS, H. L. Conseqüências ecológicas da fragmentação florestal na Amazônia. Oecologia Brasiliensis. v. 13, n. 3, p. 434-451, 2009. Available at: https://doi.org/10.4257/ oeco.2009.1303.03. Access on: 30 out. 2019.

MYERS, N. Conversion of tropical moist forests. National Research Council, National Academy of Science, Committee on Research Priorities (ed.). Tropical Biology. p. 205, Washington D. C. 1980.

NOSS, R. F.; CSUTI, B. Habitat fragmentation. In: MEFFE, G. K.; CARROLL, C. R. (Eds.) Principles of Conservation Biology. Sinauer Press, 1994.

OLIVEIRA-FILHO, A. T. Definição e delimitação de domínios e subdomínios das paisagens naturais do estado de Minas Gerais. In: SCOLFORO, JR.; CARVALHO, L. M. T. Mapeamento e Inventário da Flora e dos Reflorestamentos de Minas Gerais. Lavras: UFLA, 2006. p. 21-35.

OLIVEIRA, U. Diversidade e biogeografia de aranhas do Brasil: Esforço amostral, riqueza potencial e áreas de endemismo. 2011. 103 p. Dissertação (Mestrado). Universidade Federal de Minas Gerais, Belo Horizonte.

OTT, A. P.; OTT, R.; WOLFF, V. R. S. Araneofauna de pomares de laranja Valência nos Vales do Caí e Taquari, Rio Grande do Sul, Brasil. Iheringia, Série Zoologia, Porto Alegre, v. 97, n. 3, set. 2007. Available at: https://doi.org/10.1590/S0073-47212007000300017. Access on: 24 jun. 2020.

PLATNICK, N. I. The World Spider Catalog, version 21. American Museum of Natural History. Available at: http://research.amnh.org/iz/spiders/catalog/ Access on: 02 set. 2020.

PODGAISKI, L. R.; OTT, R.; RODRIGUES, E. N. L.; BUCKUP, E. H.; MARQUES, M. A. de L. Araneofauna (Arachnida; Araneae) do Parque Estadual do Turvo, Rio Grande do Sul, Brasil. Biota Neotropica, Campinas, v. 7. n. 2. maio/ago. 2007. Available at: https://doi.org/10.1590/\$1676-06032007000200023. Access on: 24 jun. 2020. 
REGO, F. N. A. A.; VENTICINQUE, E. M.; BRESCOVIT, A. D. Densidades de aranhas errantes (Ctenidae e Sparassidae, Araneae) em uma floresta fragmentada. Biota Neotropica, Campinas, v. 5 n. 1A, p. 45-52, fev. 2005. Available at: https://doi.org/10.1590/S1676-06032005000200004. Access on: 24 jun. 2020.

REGO, F. N. A. A.; VENTICINQUE, E. M.; BRESCOVIT, A. D. Efeitos da fragmentação florestal em quatro populações de aranhas Ctenus (Araneae: Ctenidae) na Amazônia central, Brasil. Estudos sobre Fauna Neotropical e Meio Ambiente, v. 42 n. 2, p. 137-144, abr. 2007. Available at: https://doi.org/ 10.1080/01650520600935082. Access on: 24 jun. 2020.

RINALDI, I. M. P.; MENDES, B. P.; CADY, A. B. Distribution and importance of spiders inhabiting a Brazilian sugar cane plantation. Revista Brasileira de Zoologia, Curitiba, v. 19, n. 1, jul. 2002. Available at: https://doi.org/10.1590/S0101-81752002000500021. Access on: 24 jun. 2020.

RODRIGUES, E. N. L.; MENDONCA JR., M. S.; OTT, R. Fauna de aranhas (Arachnida, Araneae) em diferentes estágios do cultivo do arroz irrigado em Cachoeirinha, RS, Brasil. Iheringia, Série Zoologia, Porto Alegre, v. 98, n. 3, set. 2008. Available at: https://doi.org/10.1590/S0073-47212008000300011. Access on: 24 jun. 2020.

RStudio Team. RStudio: IntegratedDevelopment for R. RStudio, PBC, Boston, MA. 2020. Available at: http://www.rstudio.com/. Access on: 11 abr. 2020.

RUSCHEINSKY, A. No conflito das interpretações: o enredo dasustentabilidade. Sustentabilidade: uma paixão em movimento. Revista Eletrônica do Mestrado em Educação Ambiental. Porto Alegre: Sulina, v. 10, p. 15-33, jan. 2004.

SANDIDGE, J. Predation by Cosmopolitan Spiders Upon the Medically Significant Pest Species Loxoscelesrec/usa (Araneae: Sicariidae): Limited Possibilities for Biological Control. Journal of Economic Entomology. v. 97, n. 2, p. 230-23, abr. 2004.

SORENSEN, T. A method of establishing groups of equal amplitude in plant sociology based a similarity of species. K. Danske Videnske Selsk, n. 5, p. 1-34. 1948.

SUNDERLAND, K.; SAMU, F. Effects of agricultural diversification on the abundance, distribution, and pest control potential of spiders: a review. Entomologia Experimentalis et Applicata, v. 95, p. 1-13, jan. 2000. Available at: https://doi.org/10.1046/j.1570-7458.2000.00635.x. Access on: 24 jun. 2020.

UETZ, G. W. Gradient analysis of spider communities in streamside forest. Oecologia (Berl.), v. 22, n. 4, p. 373-385. dez. 1976. Available at: https://doi.org/10.1007/bf00345314. Access on: 24 jun. 2020.

VITT, L.J.; CALDWELL, J. P. Herpetology: an introductory biology of amphibians and reptiles. Academicpress, 2013.

Received: 19/11/2019

Accepted: 24/06/2020 


\section{APPENDIX 1}

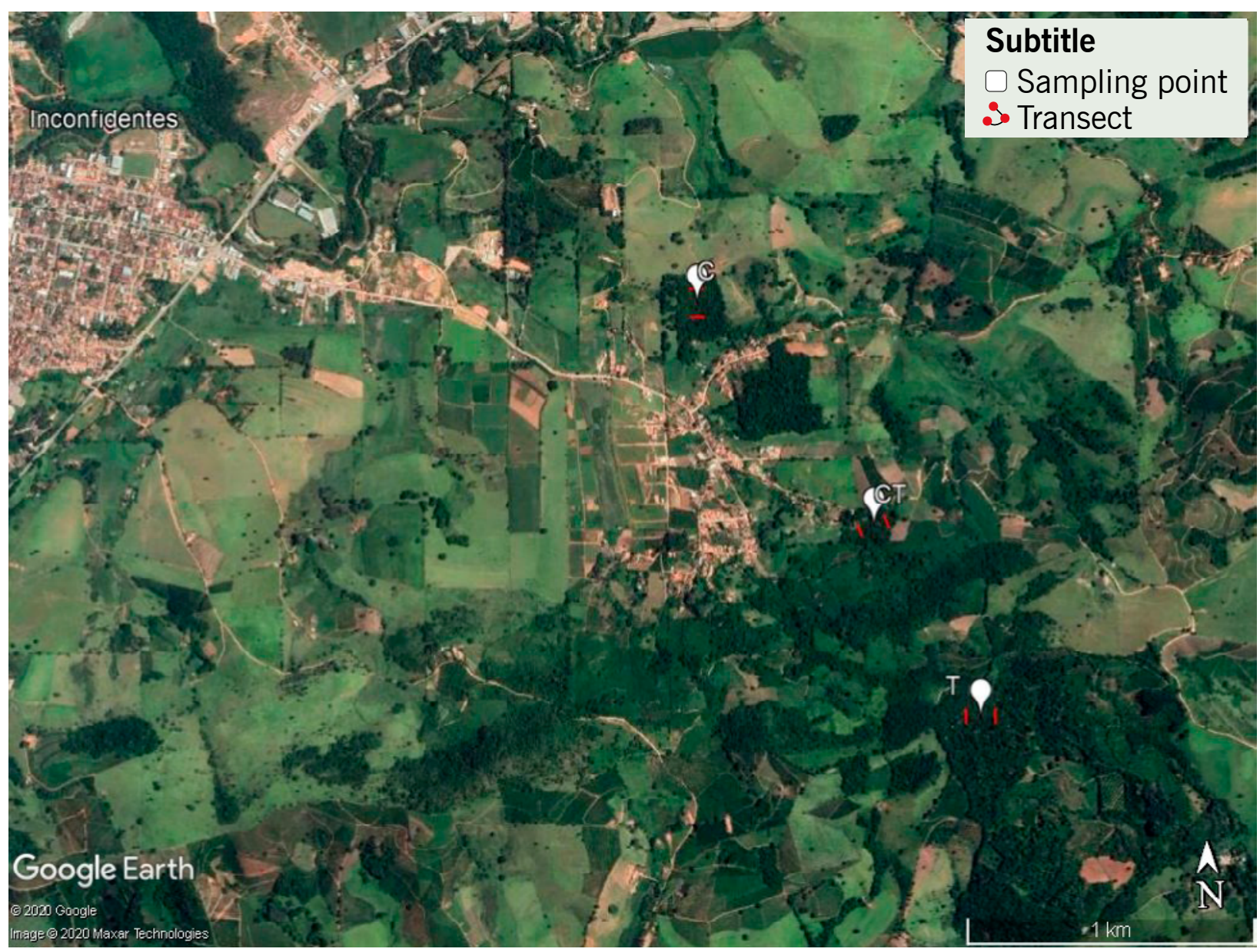

Area of forest fragments sampled (C, CT, and T), where transects of 50 meters were marked, two per fragment, for sampling spiders in the rural area of the municipality of Inconfidentes, Minas Gerais.

\section{APPENDIX 2}

Taxon and number of adult individuals per spider species collected in fragments of a montane semideciduous seasonal forest (C, CT, and T) in the municipality of Inconfidentes. Minas Gerais.

\begin{tabular}{|c|c|c|c|c|}
\hline \multirow{2}{*}{ Táxon } & \multicolumn{3}{|c|}{ Área } & \multirow{2}{*}{ Total } \\
\hline & $\mathbf{C}$ & CT & $\mathbf{T}$ & \\
\hline \multirow{2}{*}{\multicolumn{5}{|c|}{$\begin{array}{l}\text { MYGALOMORPHAE } \\
\text { Idiopidae }\end{array}$}} \\
\hline & & & & \\
\hline Idiops sp.1 & - & - & 1 & 1 \\
\hline \multicolumn{5}{|l|}{ Nemesiidae } \\
\hline Stenoterommata sp.1 & - & - & 3 & 3 \\
\hline \multicolumn{5}{|l|}{ Theraphosidae } \\
\hline Acanthoscurria sp.1 & 2 & - & 6 & 8 \\
\hline Vitalisdubius (Mello-Leitão, 1923) & - & - & 1 & 1 \\
\hline \multicolumn{5}{|l|}{ ARANEOMORPHAE } \\
\hline \multicolumn{5}{|l|}{ Anyphaenidae } \\
\hline Arachosia albiventris Mello-Leitão, 1922 & - & - & 1 & 1 \\
\hline
\end{tabular}


(Continuation)

\section{Táxon}

\begin{tabular}{lll}
\multicolumn{3}{c}{ Área } \\
\hline C & CT & T
\end{tabular}

Total

Lycosidae

Aglaoctenus lagotis (Holmberg, 1876)

Lycosa erythrognatha Lucas, 1836

Trochosa sp.1

3

4

4

Mimetidae

Gelanor sp.1

Mimetus sp. 1

1

1

Miturgidae

Miturgidae sp.1

Teminius insularis (Lucas, 1857)

$\begin{array}{cc}3 & 7 \\ 15 & 31 \\ 3 & 6\end{array}$

Oecobiidae

Oecobius navus Blackwall, 1859

Oxyopidae

Oxyopes salticus Hentz, 1845

Pholcidae

Mesabolivar sp. 1

Metagonia sp.1

Pholcus phalangioides (Fuesslin, 1775)

Smeringopus pallidus (Blackwall, 1858)

Pisauridae

Thaumasia velox Simon, 1898

4

Salticidae

Anasaitis sp. 1

Anasaitis sp.2

Chira spinosa (Mello-Leitão, 1939)

Coryphasia sp. 1

Corythalia sp.1

Cotinusa sp.1

Dendryphantinae sp.1

Dendryphantinae sp.2

Euophryinae sp.1

Maeota sp. 1

Menemerus bivittatus (Dufour, 1831)

Psecas sp. 1

Scytodidae

Scytodes tapevi Brescovit\&Rheims, 2000

Scytodes univittata Simon, 1882

Scytodes sp.1

\begin{tabular}{|c|c|c|c|}
\hline 1 & - & - & 1 \\
\hline 1 & - & - & 1 \\
\hline 21 & 8 & - & 29 \\
\hline- & 1 & - & 1 \\
\hline 1 & - & - & 1 \\
\hline 4 & 2 & - & 6 \\
\hline- & 2 & - & 2 \\
\hline- & - & 1 & 1 \\
\hline 1 & 1 & - & 2 \\
\hline- & 3 & - & 3 \\
\hline 1 & - & - & 1 \\
\hline 3 & 2 & 4 & 9 \\
\hline 1 & - & - & 1 \\
\hline- & - & 2 & 2 \\
\hline 1 & - & - & 1 \\
\hline 1 & - & 1 & 2 \\
\hline 1 & 2 & - & 3 \\
\hline- & - & 1 & 1 \\
\hline 2 & 4 & 5 & 11 \\
\hline- & - & 1 & 1 \\
\hline 3 & - & - & 3 \\
\hline 5 & 3 & 5 & 13 \\
\hline 1 & 1 & - & 2 \\
\hline 2 & - & 1 & 3 \\
\hline
\end{tabular}

Selenopidae

Selenops occultus Mello-Leitão, 1918

Selenops rapax Mello-Leitão, 1929

Sparassidae

Olios sp. 1 
(Continuation)

\begin{tabular}{|c|c|c|c|c|}
\hline \multirow{2}{*}{ Táxon } & \multicolumn{3}{|c|}{ Área } & \multirow{2}{*}{ Total } \\
\hline & $\mathrm{C}$ & CT & $T$ & \\
\hline Olios sp.2 & - & 1 & - & 1 \\
\hline Polybetes germaini Simon, 1897 & - & - & 2 & 2 \\
\hline Polybetes sp.1 & 1 & - & - & 1 \\
\hline \multicolumn{5}{|l|}{ Tetragnathidae } \\
\hline Azilia sp.1 & 3 & 2 & - & 5 \\
\hline Leucauge sp.1 & 2 & 2 & 4 & 8 \\
\hline Tetragnatha sp.1 & 1 & - & - & 1 \\
\hline \multicolumn{5}{|l|}{ Theridiidae } \\
\hline Argyrodes elevatus Taczanowski, 1873 & - & - & 2 & 2 \\
\hline Chrosiothesniteroi Levi, 1964 & 1 & - & - & 1 \\
\hline Coleosoma sp.1 & 1 & - & - & 1 \\
\hline Cryptachae arioensis (Levi, 1963) & 2 & - & - & 2 \\
\hline Cryptachaea sp.1 & 2 & - & 4 & 6 \\
\hline Cryptachaea sp.2 & 2 & - & - & 2 \\
\hline Dipoena sp.1 & 6 & - & - & 6 \\
\hline Dipoena sp.2 & 2 & - & - & 2 \\
\hline Dipoena sp.3 & 1 & - & - & 1 \\
\hline Echinotheridion cartum Levi, 1963 & 2 & - & - & 2 \\
\hline Faiditus sp.1 & 1 & - & - & 1 \\
\hline Hetschkia sp.1 & - & - & 2 & 2 \\
\hline Latrodectus geometricus C. L. Koch, 1841 & 3 & - & 9 & 12 \\
\hline Neopisinus fiapo Marques, Buckup \& Rodrigues, 2011 & 3 & 4 & 8 & 15 \\
\hline Nesticodes rufipes (Lucas, 1846) & 4 & 1 & 4 & 9 \\
\hline Nihonhimea tesselata (Keyserling, 1884) & - & 1 & 1 & 2 \\
\hline Parasteatoda tepidariorum (C. L. Koch, 1841) & - & - & 5 & 5 \\
\hline Spintharus gracilisKeyserling, 1886 & 7 & - & - & 7 \\
\hline Steatoda sp.1 & - & - & 1 & 1 \\
\hline Steatoda sp.2 & - & - & 2 & 2 \\
\hline Theridion sp.1 & 1 & - & - & 1 \\
\hline Theridion sp. 2 & 3 & - & 2 & 5 \\
\hline Thwaitesia affinis O. Pickard-Cambridge, 1882 & 22 & 8 & 14 & 44 \\
\hline \multicolumn{5}{|l|}{ Thomisidae } \\
\hline Misumenops sp.1 & - & - & 1 & 1 \\
\hline Tmarus sp. 1 & 13 & - & 17 & 30 \\
\hline Tmarus sp.2 & 2 & - & - & 2 \\
\hline \multicolumn{5}{|l|}{ Uloboridae } \\
\hline Miagrammopes sp.1 & 1 & - & - & 1 \\
\hline
\end{tabular}

